\title{
Study on the Application of Industrial Engineering Methods on Production Line Balancing Problem in T Company
}

\author{
Xiaobing Pei, Qingtao $\mathrm{Xu}^{\mathrm{a}}$ \\ School of management, Tianjin University of Technology, Tianjin 300384, China \\ axqt2266@163.com
}

Keywords: production line balance, IE methods, improvement

\begin{abstract}
This paper uses Man-Machine process analysis to improve the works performance in T company, besides, the $5 \mathrm{~W} 1 \mathrm{H}$ technique and the principles of ECRS theory are applied to restructure and optimize the work process as well as the layout of the company. Furthermore, movement based on the single piece of flow way is imported to reduce the WIP and increase the turnover rate of funds. All this approaches achieve a significant enhancement of the production capacity, production efficiency and balance rate.
\end{abstract}

\section{Introduction}

The balance of the production line is a technical means and method of averaging all the processes of production and adjusting the operating load so that the operating times are as close as possible. The purpose is to eliminate the unbalanced efficiency loss and excess production. by means of improving the efficiency of the operator and equipment, reducing the hourly consumption of single products and reducing the work in process between working procedure, Production line balancing technology can achieve the improvement of production efficiency and lay the foundation for scientific management ${ }^{[1,2]}$.

Nowadays, with the deepening of the impact of industrial engineering, more and more enterprises began to pay attention to the strength of industrial engineering, there have been many on the application of industrial engineering technology to solve practical problems in the production of research work, and a lot of practice has proved the practicality and effectiveness of industrial engineering methods. Though, more and more companies are applying industrial engineering methods to improve the performance of their plant, Industrial engineering in China's application of the proportion of enterprises is not ideal, More industrial engineering methods in the enterprise application examples will bring great help to our manufacturing enterprises to improve the management level and create more benefits ${ }^{[3]}$.

\section{Problem Description}

The T company is currently producing more varieties of small quantities. According to the product structure, its product divided into three categories: pallet type, sleeve type and adjustable type. We select the tube plus workshop as a case study. Because some of the equipment is relatively large and the value is higher, so the tube production is divided into two sections, the front stage with a single process group, and the latter part of the use of linear pipeline layout. The total number of processes in the tube plus production line is 15 . The Summary of production hours for pipe section is showed in table1. According to table1, we can see that the bottleneck of the production line is the 9th process, namely, protecting welded bracket bottom cover. The production line balance rate is as followed ${ }^{[4,5]}$ :

$$
\begin{gathered}
\text { Production line balance rate }=\frac{\sum \text { each working hour }}{\text { bottlneck working our } \times \text { number of processes }} \times 100 \% \\
=\frac{234 s}{33 s \times 15} \times 100 \%=47.27 \%
\end{gathered}
$$


Table 1. Summary of production hours for pipe plus section

\begin{tabular}{|c|c|c|c|}
\hline Serial number & Process name & Machine name & Single work hours \\
\hline 1 & Pipe cut & Automatic cutting machine & 12 \\
\hline 2 & Initial cleaning & Automatic cleaning machine & 3 \\
\hline 3 & Fine chamfering & CNC lathe & 32 \\
\hline 4 & Word rolling & Word Rolling machine & 8 \\
\hline 5 & Shrinkage & Shrink machine & 15 \\
\hline 6 & Convex welding & Convex welder & 8 \\
\hline 7 & $\begin{array}{c}\text { Press the bottom } \\
\text { cover }\end{array}$ & Capping machine & 7 \\
\hline 8 & Press the bracket & Press bracket machine & 15 \\
\hline 9 & $\begin{array}{l}\text { Protecting welded } \\
\text { bracket bottom cover }\end{array}$ & Robot welding machine & 33 \\
\hline 10 & $\begin{array}{l}\text { Protecting welding } \\
\text { plate }\end{array}$ & Protection welding machine & 23 \\
\hline 11 & $\begin{array}{c}\text { Spot welding spring } \\
\text { plate }\end{array}$ & Manual spot welding & 12 \\
\hline 12 & $\begin{array}{l}\text { Protecting welding } \\
\text { spring plate }\end{array}$ & Protection welding machine & 22 \\
\hline 13 & Clean the slag & Manual & 22 \\
\hline 14 & Leaks detection & Leak machine & 16 \\
\hline 15 & Cleaning and drying & Automatic cleaning machine & 6 \\
\hline
\end{tabular}

\section{Improvement and Optimization}

According to customer needs, the production line's cycle time is $23.96 \mathrm{~s}$, and there are two processes which work ours is beyond the cycle time. That is the 3th Fine chamfering process and the 9th protecting welded bracket bottom cover process.

\subsection{Analysis of Man - Machine Operation}

Take the 9th process as case, through man-machine joint operation analysis, we learned the utilization of personnel is only $30.3 \%$, and the machine is $69.69 \%$. The leisure capacity analysis shows that the operator can operate 3 sets of machines at the same time. So our Improvement program is accordingly made as follows: the original single table to double table, the robot through the programming control alternately welded two parts, the machine utilization rate increased to $100 \%$, processing a product cycle time from $33 \mathrm{~s}$ to $23 \mathrm{~s}$, to improve efficiency $30.3 \%$, to improve the postcycle time also reached less than or equal to the requirements of the cycle time. After the improvement plan was established, the man-machine joint operation analysis was performed on the 9th process, as showed in figure 1.

\subsection{Production Line Balance Optimization}

In the process of balance optimization of the production line, the priority of the production process is determined first, then the production process is optimized according to the beat time and ECRS principle and the production line station is determined. The production line balance rate is maximized in accordance with the beat time. The scheduling scheme determines the line layout. After the operation of improvement all processes can meet customer rhythm requirements. After the internal operations of each process are refined, the pipeline is balanced according to the job order and the operating time, and the station is divided according to the ECRS principle.

Refinement of the work process After the division of the station, in line with the requirements of the rhythm of a production line staff configuration only 4 people, the maximum cycle time of the production line is $24.6 \mathrm{~s}$.

$$
\begin{gathered}
\text { Production line balance rate }=\frac{\text { Seach working hour }}{\text { bottlneck working our } \times \text { number of processes }} \times 100 \% \\
=\frac{96.3 \mathrm{~s}}{24.6 s \times 4} \times 100 \%=97.86 \%
\end{gathered}
$$




\begin{tabular}{|c|c|c|c|c|c|c|c|}
\hline \multirow{2}{*}{\multicolumn{2}{|c|}{$\begin{array}{c}\text { Machine } \\
\text { Process name }\end{array}$}} & \multirow{4}{*}{$\begin{array}{c}\text { Robot welding machine } \\
\begin{array}{c}\text { Protecting welded bracket } \\
\text { bottom cover }\end{array} \\
24 \\
46 \\
\end{array}$} & \multirow{2}{*}{\multicolumn{2}{|c|}{$\begin{array}{c}\text { Department } \\
\text { Tube plus shop }\end{array}$}} & Team & \multirow{2}{*}{\multicolumn{2}{|c|}{$\begin{array}{c}\text { Date } \\
2016.6 .20\end{array}$}} \\
\hline & & & & & $\mathrm{IE}$ & & \\
\hline \multirow{2}{*}{$\begin{array}{l}\text { Work } \\
\text { time }\end{array}$} & Man & & \multirow{2}{*}{$\begin{array}{l}\text { Leisure } \\
\text { time }\end{array}$} & Man & 22 & \multirow{2}{*}{$\begin{array}{l}\text { Total } \\
\text { time }\end{array}$} & \multirow{2}{*}{46} \\
\hline & Machine & & & Machine & 0 & & \\
\hline Utilization & Man & $52.17 \%$ & \multicolumn{2}{|c|}{ Machine } & \multicolumn{3}{|c|}{$100.00 \%$} \\
\hline Time/s & \multicolumn{2}{|r|}{ Man } & \multicolumn{3}{|c|}{ Machine } & \multicolumn{2}{|c|}{ Time/s } \\
\hline 11 & & $\begin{array}{l}\text { Waiting for the machine to } \\
\text { finish }\end{array}$ & \multirow{2}{*}{\multicolumn{2}{|c|}{$\begin{array}{l}\text { The protective door is } \\
\text { open and the robot starts } \\
\text { welding the work piece on } \\
\text { the B table }\end{array}$}} & & \multirow{2}{*}{\multicolumn{2}{|c|}{22}} \\
\hline 6 & & $\begin{array}{l}\text { Remove the finished product on } \\
\text { the A work piece, visual } \\
\text { welding quality; qualified } \\
\text { products into the finished } \\
\text { product turnover, the defective } \\
\text { goods into the repair box }\end{array}$ & & & & & \\
\hline 6 & & $\begin{array}{l}\text { Remove the blank from the } \\
\text { transfer car, put it on the A } \\
\text { work piece table positioning, } \\
\text { start the switch }\end{array}$ & \multicolumn{2}{|c|}{$\begin{array}{l}\text { Welding finished, gun } \\
\text { recovery }\end{array}$} & & \multicolumn{2}{|l|}{1} \\
\hline 6 & & $\begin{array}{l}\text { Remove the finished product on } \\
\text { the B work piece, visual } \\
\text { welding quality; qualified } \\
\text { products into the finished } \\
\text { product turnover, the defective } \\
\text { goods into the repair box }\end{array}$ & \multirow{2}{*}{\multicolumn{2}{|c|}{$\begin{array}{l}\text { The protective door is } \\
\text { open and the robot starts } \\
\text { welding the work piece on } \\
\text { the A table }\end{array}$}} & & \multirow{2}{*}{\multicolumn{2}{|c|}{22}} \\
\hline 6 & & $\begin{array}{l}\text { Remove the blank from the } \\
\text { transfer car, put it on the B } \\
\text { work piece table positioning, } \\
\text { start the switch }\end{array}$ & & & & & \\
\hline 11 & & $\begin{array}{l}\text { Waiting for the machine to } \\
\text { finish }\end{array}$ & $\begin{array}{r}\text { Welding } \\
\text { re }\end{array}$ & $\begin{array}{l}\text { shed, gun } \\
\text { ery }\end{array}$ & & 1 & \\
\hline 6 & & $\begin{array}{l}\text { Remove the finished product on } \\
\text { the A work piece, visual } \\
\text { welding quality; qualified } \\
\text { products into the finished } \\
\text { product turnover, the defective } \\
\text { goods into the repair box }\end{array}$ & \multirow{2}{*}{\multicolumn{2}{|c|}{$\begin{array}{l}\text { The protective door is } \\
\text { open and the robot starts } \\
\text { welding the work piece on } \\
\text { the B table }\end{array}$}} & & \multirow{2}{*}{\multicolumn{2}{|c|}{22}} \\
\hline 6 & & $\begin{array}{l}\text { Remove the blank from the } \\
\text { transfer car, put it on the A } \\
\text { work piece table positioning, } \\
\text { start the switch }\end{array}$ & & & & & \\
\hline 11 & & $\begin{array}{l}\text { Waiting for the machine to } \\
\text { finish }\end{array}$ & $\begin{array}{r}\text { Welding } \\
\text { re }\end{array}$ & $\begin{array}{l}\text { nished, gun } \\
\text { very }\end{array}$ & & 1 & \\
\hline
\end{tabular}

Fig1. Man-Machine joint operation analysis

\section{Analysis on the Improvement of Production Line Balance}

According to the actual situation of enterprises, reorganize the tube plus production process and improve the bottleneck process, shorten the cycle time to meet the customer rhythm requirements. Through the re-layout of the production line, the production of a basic realization of the single stream, handling waste greatly reduced. It is important to improve the efficiency of the work and improve the balance of the production line after the process steps are refined and re-scheduled. Comparison of production line improvement of the relevant data is showed in table2. 
Table2 Comparison of production line improvement

\begin{tabular}{ccccccc}
\hline & $\begin{array}{c}\text { Number } \\
\text { of Direct } \\
\text { operator }\end{array}$ & $\begin{array}{c}\text { Maximum } \\
\text { cycle time/s }\end{array}$ & $\begin{array}{c}\text { Hourly } \\
\text { output/pcs }\end{array}$ & $\begin{array}{c}\text { Unit } \\
\text { capacity/pcs }\end{array}$ & $\begin{array}{c}\text { Line balance } \\
\text { rate/\% }\end{array}$ & $\begin{array}{c}\text { Work in } \\
\text { progress/pcs }\end{array}$ \\
\hline $\begin{array}{c}\text { Before } \\
\text { improvement } \\
\text { After }\end{array}$ & 6 & 33 & 109 & 18.2 & 47.27 & 1200 \\
improvement & 4 & 24.6 & 146.3 & 36.6 & 97.86 & 15 \\
\hline
\end{tabular}

\section{Conclusion}

This paper studies the application of industrial engineering methods in $\mathrm{T}$ company, through the training of industrial engineering theory and carrying out related improvement activities, all staff of the company have a better understanding of industrial engineering, and they are more willing to take part in the progress, which is very important for the company in the future.

There are still many factors and methods to be considered in the improvement progress, such as action analysis, Layout analysis, PTS method in the production line balance process are worth doing further research.

\section{References}

[1]LU Haiyang, LI Jizu. Application of Industrial Engineering Methods in Balancing of Production Line of Company F. [J] Logistics Technology, 2014.2:295-299.

[2]SHI Yuqiang. Research on Improvement of Production Line Based on IE.[J] Machinery, 2009, 3:57-59.

[3]ZHANG Xuelong, W, X, SH. Enterprise Production Line Optimization and Re-design based on Work Study Methods-A Case Study.[J]Modern Manufacturing Engineering,2015,3:27-32.

[4]YI Shuping, GUO Fu. Basic Industrial Engineering.[D]BEI JING, China Machine Press,2007.

[5]GAO Guangzhang. Study on Balance and Optimization of Production Line.[D]CHANG CHUN,JI LIN University, 2004. 